\title{
Levels and trends of PCDD/Fs and PCBs in camel milk (Camelus bactrianus and Camelus dromedarius) from Kazakhstan
}

\author{
Gaukhar Konuspayeva ${ }^{\mathrm{a}}$, Bernard Faye ${ }^{\mathrm{b}}$, Edwin De Pauw ${ }^{\mathrm{c}}$, Jean-François Focant ${ }^{\mathrm{c}, *}$ \\ a Al Farabi Kazakh National University, Avenue Al Farabi 71, 050040 Almaty, Kazakhstan \\ ${ }^{\mathrm{b}}$ CIRAD, Campus International de Baillarguet, 34398 Montpellier cedex, France \\ ${ }^{\mathrm{C}}$ CART, Biological and Organic Analytical Chemistry, Mass Spectrometry Laboratory, University of Liège, Allée de la Chimie 3, B-6c Sart-Tilman, B-4000 Liège, Belgium
}

\section{A R T I C L E I N F O}

\section{Article history:}

Received 19 February 2011

Received in revised form 14 June 2011

Accepted 23 June 2011

Available online 22 July 2011

\section{Keywords:}

Polychlorinated dibenzo-p-dioxins (PCDDs)

Polychlorinated dibenzofurans (PCDFs)

Polychlorinated biphenyls (PCBs)

Camel milk

Kazakhstan

Geographical trends

\begin{abstract}
A B S T R A C T
To date, despite the fact it represents a very important part of the national dairy production, no data are available concerning the concentrations of polychlorinated dibenzo-p-dioxins (PCDDs), polychlorinated dibenzofurans (PCDFs), and polychlorinated biphenyls (PCBs) in camel milk from the Republic of Kazakhstan. Selected PCDDs, PCDFs, and PCBs were measured in pools of milk from camels $(n=15)$ located in various places of Kazakhstan (Almaty, Atyrau, Aralsk, Shymkent) and sampled at two different seasons for two different species (Camelus bactrianus and Camelus dromedarius). Non-dioxin-like (NDL)PCB concentrations ( $6.3 \pm 2.7 \mathrm{ng} \mathrm{g}^{-1}$ fat, median $5.1 \mathrm{ng} \mathrm{g}^{-1}$ fat, range $0.6-17.4 \mathrm{ng} \mathrm{g}^{-1}$ fat) were far below the maximum value of $40 \mathrm{ng} \mathrm{g}^{-1}$ fat proposed by the EU. Dioxin-like (DL-)PCB concentrations $\left(1.7 \pm 0.7 \mathrm{ng} \mathrm{g}^{-1}\right.$ fat, median $1.5 \mathrm{ng} \mathrm{g}^{-1}$ fat, range $0.3-4.2 \mathrm{ng} \mathrm{g}^{-1}$ fat) and the NDL-PCB to DL-PCB ratio (4.3) were similar to what is reported in EU for cow-based dairy products. PCB 52 and PCB 101 appeared to be proportionally more present in Kazakh camel milk samples $(>60 \%$ of the sum of the 6 indicator NDL-PCBs) than in European cow milk samples ( $<10 \%$ of the sum of the 6 indicator NDL-PCBs), indicating possible differences in the route of exposure to PCBs in Kazakhstan. PCB 105 and PCB 118 appeared to be present at higher concentrations in camel milk (>80\% of the sum of the 12 DL-PCBs). PCB 105, PCB 118 and PCB 156 were the major congeners for DL-PCBs, accounting for $92 \%$ of the sum of concentrations of DL-PCBs (88\% for Belgian cows). In terms of TEQ, PCB 126 and PCB 118 are the major contributors and represent, respectively, $80 \%$ and $14 \%$ of the DL-PCB TEQ ${ }_{w H O 05}$ concentrations. No significant interracial or geographical trends were observed for NDL- and DL-PCB profiles. However, concentrations of all DL-PCBs appeared to be significantly higher for samples collected in Atyrau region. 2,3,7,8-TCDD level (mean $0.08 \pm 0.07 \mathrm{pg} \mathrm{g}^{-1}$ fat, median $0.08 \mathrm{pg} \mathrm{g}^{-1}$ fat, range $0.00-0.18 \mathrm{pg} \mathrm{g}^{-1}$ fat, $60 \%>$ LOQs) were very low for all samples and 2,3,4,7,8-PeCDF was the major contributor (27\%) to the PCDD/F TEQ ${ }_{\text {who05. Con- }}$ sidering the total TEQ ${ }_{\text {wHO05 }}$ (sum of DL-PCBs and PCDD/Fs), DL-PCB and PCDD/F contributed for $73 \%$ and $27 \%$, respectively. A decrease of only $1 \%$ of the total TEQ was observed when using the $\mathrm{TEF}_{\mathrm{WHO}}$ scale instead of the TEF $\mathrm{WHO}_{3}$ scale. Two samples collected in the region of Atyrau exceeded the EU maximum level value of $6.00 \mathrm{pg} \mathrm{TEQ}_{\text {WHO98 }} \mathrm{g}^{-1}$ fat $\left(6.4 \mathrm{pg} \mathrm{TEQ}_{\text {WHO05 }} \mathrm{g}^{-1}\right.$ fat and $6.9 \mathrm{pg} \mathrm{TEQ}_{W H O 05} \mathrm{~g}^{-1}$ fat). Both samples exceeded the EU action level for the sum of DL-PCBs. Based on the fact that camel milk is used to prepare popular traditional fermented drinks like shubat, this suggests that the human exposure in the Caspian Sea region of Atyrau should be expected to be higher than in the other regions studied here.
\end{abstract}

(c) 2011 Elsevier Ltd. All rights reserved.
Abbreviations: POPs, persistent organic pollutants; WHO, World Health Organization; PCDDs, polychlorinated dibenzo-p-dioxins; PCDFs, polychlorinated dibenzofurans; PCBs, polychlorinated biphenyls; NO-PCBs, non-ortho PCBs; MOPCBs, mono-ortho PCBs; DL-PCBs, dioxin-like PCBs; NDL-PCBs, non-dioxin-like PCBs; TCDD, tetrachlorodibenzo-p-dioxins; TCDF, tetrachlorodibenzofuran; PeCDD, pentachlorodibenzo-p-dioxins; PeCDF, pentachlorodibenzofuran; HxCDD, hexachlorodibenzo-p-dioxins; HxCDF, hexachlorodiben zofuran; HpCDD, heptachlorodibenzo-p-dioxins; HpCDF, heptachlorodibenzofuran; OCDD, octachlorodibenzo- $p$-dioxins; OCDF, octachlorodibenzofuran; GC-IDHRMS, gaz chromatography coupled to isotope dilution mass spectrometry; QC, quality control; TEF, toxic equivalency factor; TEQ ${ }_{w H O 98}$, toxic equivalent following 1998 WHO TEF scale; TEQ ${ }_{\text {WHO05, }}$ toxic equivalent following 2005 WHO TEF scale.

* Corresponding author. Tel.: +32 (0)4 36635 31; fax: +32 (0)4 3664387.

E-mail address: JF.Focant@ulg.ac.be (J.-F. Focant).

\section{Introduction}

Kazakhstan is a large country $\left(2717300 \mathrm{~km}^{2}\right)$ that is approximately $80 \%$ desert and steppe with only around $15.5 \times 10^{6}$ inhabitants and that is made of approximately $80 \%$ of desert and steppe. Around $40 \%$ of the total Kazakhstan population leaves in rural regions and depends on traditional breeding of cattle. The main feeding resources for those cattle are the natural pastures located in various places of the country. Pasture resources have been reduced since 1960 s by conversion into agricultural zones that further reduced the water reserves near the remaining grazing areas. Additionally, the end of the Soviet Union has been followed by an 
important decrease of all livestock and today's number are not yet back to the pre-independency situation. Currently, livestock are mainly made of cattle, sheep, horse, and camel. The particularity of Kazakhstan is to breed horses and camels in addition to cows for dairy production. There are however, to our best knowledge, no national statistical data available for horse and camel milk production, but it could represent more than $25 \%$ of the whole consumed milk in the country. The milk from those two non-conventional dairy animals is generally transformed and consumed in traditional fermented drinks called kumis for horses and shubat for camels. This is specific to Central Asia steppes where traditional preparation procedures are culturally important. Those liquid preparations can somewhat be compared to the cheese preparation in Western European countries.

Physicochemical properties of camel milk are quite different from cow milk properties: higher triglyceride and mono-saturated fatty acids content, lower thermal stability, better buffer properties, high content in vitamin C (Rüegg and Farah, 1991; Faye et al., 2008; Konuspayeva et al., 2008). Additionally, camel milk is reported to exhibit anti-infectious properties (Djangabilov et al., 2000), to stimulate the immune system (Yagil and Van Creveld, 2000), to reduce insulin dependency in diabetes patients (Agrawal et al., 2003), to have a stimulating effect and anti-allergenic properties (Restani et al., 1999). Camel milk also contains significantly higher concentrations of lactoferrin (El-Hatmi et al., 2006) (used in cancer treatments) and immunoglobulin G (IgG, important in early stage of life) than cow milk (El Agamy, 2000; Konuspayeva et al., 2006), which makes it of interest as a substitute for cow milk. For those reasons, camel milk and derivatives are very popular in several countries of Central Asia like Kazakhstan where one estimate is more than 150000 the number of camels reared for milk production (Food and Agriculture Organization of the United Nations, 2010). It results in an important camel milk consumption (30-35 kg person ${ }^{-1}$ year $^{-1}$ ), especially in rural regions (Agency of Statistic of the Republic of Kazakhstan, 2010). Large-scale milk factories based on camel milk are however quite rare and not subject to clear regulations in terms of quality control.

Certain places in Central Asian Republics are known to be potentially contaminated by toxic compounds like radio nuclides, heavy metals, persistent organic pollutant (POPs), ... (Faye and Sinyavskiy, 2008; Konuspayeva et al., 2011). The ecologically threatened Aral and Caspian seas in southwest, the former nuclear testing site of Semipalatinsk in the north east, several chemical and petrochemical plants, many cotton growing farms, as well as mining industries and uncontrolled waste burning and disposal are example of ruthless exploitation of natural resources and make Kazakhstan of real concern in terms of pollution monitoring (Baranik et al., 2004; Erdinger et al., 2004). In terms of POPs, large quantities of organochlorine pesticides have been (are potentially still) used to control parasites and increase the yield of cotton for intensive farming. In addition, industrial pollutants such as polychlorinated biphenyls (PCBs) and polychlorinated dibenzop-dioxins (PCDDs) and polychlorinated dibenzofurans (PCDFs) are also released and accumulate at various levels in the environment and food chain (Lederman, 1996; Jensen et al., 1997).

There are a few publications on PCB and PCDD/F concentrations in the Kazakhstan population. In 1998, She et al. reported concentrations of PCBs measured in mother milk samples collected in rural and urban areas of Southern Kazakhstan to be lower or similar to concentrations measured in Western Europe. Lutter et al. (1998) reported similar findings, but highlighted the exception of rural cotton growing areas of Djetisay and Kyrov where 2,3,7,8-substituted tetrachlorinated dibenzo-p-dioxin $(2,3,7,8$-TCDD) concentrations were similar to those reported for breast milk collected in South Vietnam in the early 1970s at the time Agent Orange was sprayed by US troops. Hooper et al. (1998) also reported elevated
2,3,7,8-TCDD and 1,2,3,7,8-substituted pentachlorodibenzop-dioxin (1,2,3,7,8-PeCDD) concentrations in mother milk collected in 1994 and 1996 in rural areas where state farms were located. In the rural region, TCDD concentrations in breast milk did not correlate with cottonseed oil consumption, although it did correlate with kefir (a creamy drink made of fermented cow's milk) consumption. The probable source of dioxin exposure was related to aerial application of potentially TCDD contaminated 2,4,5-trichlorophenoxyacetic acid $(2,4,5-\mathrm{T})$ defoliant in cotton growing agricultural regions of Southern Kazakhstan (Hooper et al., 1999). It was further reported that TCDD was also detected in some foodstuffs of animal origin like cow's milk, lamb and butter. Despite the evidence of exceptionally high concentrations for a specifically exposed part of the population, those studies concluded that promotion of good breastfeeding practices and continuation of breastfeeding should still be recommended in Kazakhstan.

Although Western European cow milk production is continuously monitored for PCDD/Fs and PCBs, no controls are performed in Kazakhstan and virtually no data are even available concerning concentrations in foodstuffs of animal origin, especially camels. In this study, a sampling plan was designed to estimate the background concentrations of $35 \mathrm{PCDD} / \mathrm{F}$ and PCB in milk of Bactrian camels (double humped) and dromedaries (Arvana breed) located in various places of Kazakhstan (Almaty, Atyrau, Aralsk, Shymkent).

\section{Experimental}

\subsection{Chemicals}

All data concerning the quality and potential pre-treatment of the entire set of chemical used for those analyses are available in a previous report (Focant et al., 2001). All isotope dilution calibration, internal, and recovery standards were purchased from Cambridge Isotope Laboratory (Cambridge Isotope Laboratories Inc., Andover, MS, USA). A labelled internal standard (I.S.) solution made of a mixture of the ${ }^{13} \mathrm{C} P C D D / F s$ and $\mathrm{PCBs}$ was prepared to facilitate the spiking procedure of the samples. All standards were in nonane.

Quality control (QC) samples consisted of a home made pool of cow milk fortified with the PCDD, PCDF, and DL-PCB congeners at a level below the EU regulation value ( $6 \mathrm{pg}$ WHO-PCDD/F-PCB $\mathrm{TEQ}^{-1}$ fat) (Commission Regulation 1881, 2002). The PCDD/F TEQs and DL-PCB TEQs of those QC samples were calculated and plotted against reference values obtained from validation replicates. Classical Shewhart control charts were used to ensure proper measurements. QC samples related to the present study did comply with regular QC chart rules and all data were inside the \pm 2 $\mathrm{SD}$ interval. All other $\mathrm{QA} / \mathrm{QC}$ criteria are similar to those we routinely use for food control under EU regulation (Focant et al., 2002; Focant et al., 2003).

\subsection{Sample collection and storage}

A total of 127 camel milk samples were collected for the present study. They originated from four regions of Kazakhstan (Almaty, Atyrau, Aralsk and Shymkent) (Fig. 1) and the milk was collected at two different seasons (spring and fall). Samples came from 57 Kazakh Bactrian camels (double humped) and 70 dromedaries (Arvana breed). This sampling procedure aimed to maximize the observed variability. All samples were collected at the end of milking, kept refrigerated until they reached the laboratory, then frozen and stored at $-18{ }^{\circ} \mathrm{C}$. Samples collected at the same season and originating from the same region were pooled. This resulted in 15 composite samples (two seasons, two species, four regions, with no data for fall milk samples of dromedaries in Aralsk). The lipid content of each pooled sample was determined gravimetrically. 


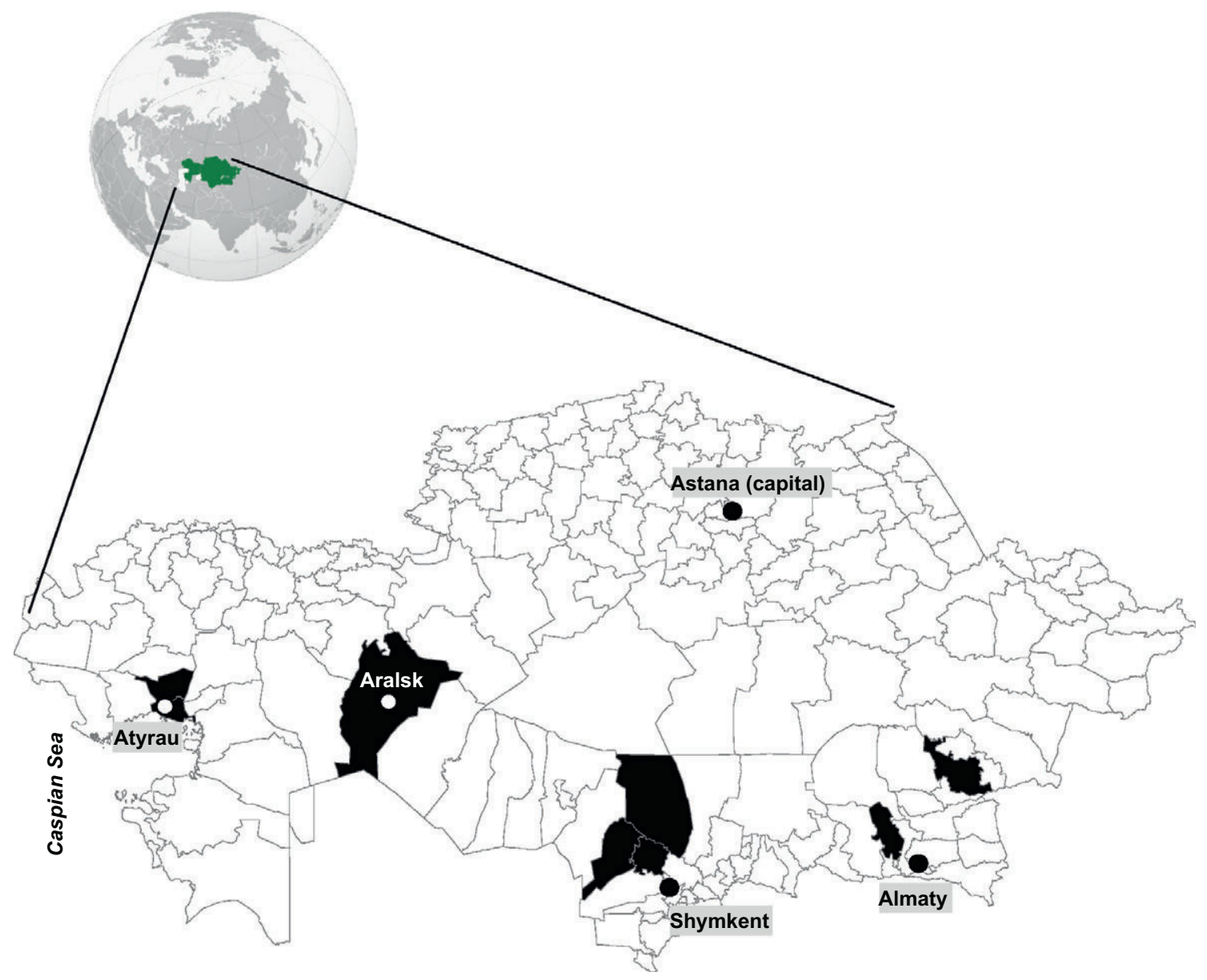

Fig. 1. Cartography of the sampling sites in Kazakhstan.

\subsection{Sample preparation and quality control}

Measurements were performed on 15 pooled samples. All samples were processed in series of routinely analyzed samples (one method blank, one instrumental blank, one QC and 10 unknown) in an ISO17025 BELAC accredited laboratory. Sample sizes ranged between 35 and $50 \mathrm{~mL}$. Each pool was liquid-liquid extracted. For this particular study, a modified method was used. Ethanol $(40 \mathrm{~mL})$ and ammoniac $(10 \mathrm{~mL})$ were added to $50 \mathrm{~mL}$ of milk in a separatory funnel. Diethyl ether $(50 \mathrm{~mL})$ was added after 1 min of shaking. The mixture was shaken for one more minute and let stand until phase separation. Hexane $(50 \mathrm{~mL})$ was then added and the solution was gently agitated. The aqueous layer was discarded after $15 \mathrm{~min}$ of gravimetric phase separation. For blank samples, the same sample procedure was used but water replaced the milk sample. The organic phase was dried over $20 \mathrm{~g}$ of sodium sulfate placed on a paper filter inserted in a funnel and pumped with a water pump. The solvent was removed by a rotary evaporator at $30^{\circ} \mathrm{C}$ and reduced pressure. The fat residue was weighed until constant weight (less than $1.5 \%$ variation). This weight was defined as the lipid content of samples. The fat was dissolved again in $50 \mathrm{~mL}$ of hexane and spiked with the internal standard that contained all analytes of interest.

The first step of sample clean-up was a multilayer silica gel column in a disposable glass column plugged with glass wool. From bottom to top, it contained $5 \mathrm{~g}$ of sodium sulfate, $5 \mathrm{~g}$ of silicagel, $20 \mathrm{~g}$ of $44 \%$ sulfuric acid silica gel, and $20 \mathrm{~g}$ of $22 \%$ sulfuric acid silica gel. It was washed with $150 \mathrm{~mL}$ of hexane before use. The fat sample was applied on the column and eluted with $150 \mathrm{~mL}$ of hexane. The volume of the eluate was reduced to $20 \mathrm{~mL}$ before the next step. Further sample clean-up was achieved using an automated system (Power-Prep ${ }^{\mathrm{TM}}$, Fluid Management Systems Inc., Waltham, MA, USA) (Focant et al., 2004). The final volumes were $40 \mu \mathrm{L}$ for the MO- and NDL-PCBs fraction and $5 \mu \mathrm{L}$ for the PCDD/Fs and NO-PCBs fraction. For the MO- and NDL-PCBs fraction, $10 \mu \mathrm{L}$ of syringe (recovery) standards (PCB-80) were added to the GC vials prior to injection in GC-IDHRMS. For the PCDD/Fs and NO-PCBs fraction, $5 \mu \mathrm{L}$ of EDF-4145 were added.

\subsection{Instrumentation}

Measurements of MO-PCBs and NDL-PCBs were carried out on a MAT95 XL (ThermoFinniganMAT, Bremen, Germany). The GC column was an HT-8 $(25 \mathrm{~m} \times 0.22 \mathrm{~mm}$ ID $\times 0.25 \mu \mathrm{m} \mathrm{df})$ (SGE, Villebon, France). $1.2 \mu \mathrm{L}$ of the final extract in nonane $(95 \mu \mathrm{L})$ were injected into a split/splitless injector held at $275^{\circ} \mathrm{C}$ in splitless mode. Measurements of PCDDs, PCDFs, and NO-PCBs were carried out on an Autospec Ultima (Micromass, Manchester, United Kingdom) The GC column was a VF-5MS ( $50 \mathrm{~m} \times 0.2 \mathrm{~mm}$ ID $\times 0.33 \mu \mathrm{m} \mathrm{df})$ (Varian Inc., Sint-Katelijne-Waver, Belgium). Five microliters of the final extract in nonane $(10 \mu \mathrm{L})$ were injected into programmable temperature vaporization (PTV) injector (Agilent Technologies, Diegem, Belgium). For both injections, Helium was used as the carrier gas at constant flow rate of $1.2 \mathrm{~mL} \mathrm{~min}^{-1}$ and the HRMS instrument was operated in selected ion monitoring (SIM) mode. Two ions were monitored for both native and labels for isotope ratio check. Additional GC and HRMS parameters were described previously (Focant et al., 2006). Both instrumental and procedural blanks (BCs) were 
monitored. Sensitivity checks of the instrument were carried out on a daily basis. In accordance with EU Commission Directive 2002/70/ EC, all TEQ values were based on upper bound data (Commission Directive 2002/70/EC, 2002).

\section{Results and discussion}

\subsection{Lipid contents}

The mean value for all samples (by weight) was $4.7 \pm 1.2 \%$ (median 4.3\%, range 3.3-7.4\%). No significant differences were observed between camel species or in relation with seasonal sampling (Fig. S1, Supplementary data). The mean value for Bactrian was larger $(5.3 \pm 1.3 \%)$ than for dromedary $(4.4 \pm 0.8 \%)$, but both groups were characterized by the same median lipid content values of $4.3 \%$. The lower and higher lipid contents were observed for dromedary in spring (mean $4.2 \pm 0.5 \%$, median $4.2 \%$ ), and Bactrian in spring (mean $5.3 \pm 1.3 \%$, median $5.0 \%$ ), respectively. From all samples, Bactrian in fall expressed the larger lipid content range (3.3-7.4\%). Although one could have expected somewhat lower lipid content for spring samples because of potentially lower food intake during winter season, those data do not describe a clear seasonal influence on the lipid content for both species. Globally, the reported mean values are similar to the few available values for Kazakhstan, as reported by Konuspayeva et al. (2010) $5.9 \pm 2.5 \%$, Serikbaeva and Toktamysova, 2000 5.2\%, and Urbisinov (unpublished results) $5.1 \%$.

\subsection{NDL-PCB concentrations}

The mean NDL-PCB level, based on the sum of PCB 28, PCB 52, PCB 101, PCB 138, PCB 153, and PCB 180 for all samples was $6.3 \pm 2.7 \mathrm{ng} \mathrm{g}^{-1}$ fat (median $5.1 \mathrm{ng} \mathrm{g}^{-1}$ fat, range $0.6-17.4 \mathrm{ng} \mathrm{g}^{-1}$ fat) (Table 1). From a recent European Food Safety Authority (EFSA) report (EFSA, 2010a) based on data issued form $18 \mathrm{EU}$ member states, Iceland, and Norway $(n=5640)$, the mean of the sum of the 6 indicator NDL-PCBs for dairies in Europe is $9.2 \pm 3.4 \mathrm{ng} \mathrm{g}^{-1}$ fat (median $9.0 \mathrm{ng} \mathrm{g}^{-1}$ fat). Although the mean value might be biased by samples issued from specific contamination incidents, the comparison of the median values indicates that Kazakh camels were showing NDL-PCB concentrations below European cows. Those concentrations are well below the maximum level of

Table 1

Average concentrations (fat basis) of selected PCDDs, PCDFs, and PCBs measured in camel milk (Bactrian and dromedary, $n=15$ pooled samples) collected in various region of Kazakhstan.

\begin{tabular}{|c|c|c|c|c|c|c|c|}
\hline & \multirow[t]{2}{*}{ Mean $^{\mathrm{a}}$ Conc. $\left(\mathrm{pg} \mathrm{g}^{-1}\right)$} & \multirow[t]{2}{*}{ SD conc. $\left(\mathrm{pg} \mathrm{g}^{-1}\right)$} & \multirow[t]{2}{*}{ Median ${ }^{\mathrm{a}}$ Conc. $\left(\mathrm{pg} \mathrm{g}^{-1}\right)$} & \multirow[t]{2}{*}{ LOQs } & \multirow[t]{2}{*}{$\%>\mathrm{LOQ}$} & \multicolumn{2}{|l|}{ Range $^{a}$} \\
\hline & & & & & & Min & Max \\
\hline \multicolumn{8}{|l|}{ Dioxins } \\
\hline 2,3,7,8-TetraCDD & 0.08 & 0.07 & 0.08 & 0.07 & 60 & 0.00 & 0.18 \\
\hline 1,2,3,7,8-PentaCDD & 0.20 & 0.10 & 0.18 & 0.10 & 93 & 0.00 & 0.40 \\
\hline 1,2,3,4,7,8-HexaCDD & 0.05 & 0.08 & 0.00 & 0.11 & 40 & 0.00 & 0.20 \\
\hline 1,2,3,6,7,8-HexaCDD & 0.14 & 0.10 & 0.13 & 0.08 & 80 & 0.00 & 0.32 \\
\hline 1,2,3,7,8,9-HexaCDD & 0.00 & 0.00 & 0.00 & 0.11 & 0 & 0.00 & 0.00 \\
\hline $1,2,3,4,6,7,8$-HeptaCDD & 0.00 & 0.00 & 0.00 & 2.51 & 0 & 0.00 & 0.00 \\
\hline OctaCDD (OCDD) & 0.00 & 0.00 & 0.00 & 12.20 & 0 & 0.00 & 0.00 \\
\hline Furans & & & & & & & 0.00 \\
\hline 2,3,7,8-TetraCDF & 0.00 & 0.00 & 0.00 & 0.60 & 13 & 0.00 & 0.00 \\
\hline 1,2,3,7,8-PentaCDF & 0.04 & 0.06 & 0.00 & 0.07 & 40 & 0.00 & 0.16 \\
\hline 2,3,4,7,8-PentaCDF & 0.64 & 0.48 & 0.63 & 0.35 & 80 & 0.00 & 1.65 \\
\hline $1,2,3,4,7,8-\mathrm{HexaCDF}$ & 0.23 & 0.28 & 0.00 & 0.30 & 47 & 0.00 & 0.78 \\
\hline $1,2,3,6,7,8-$ HexaCDF & 0.35 & 0.27 & 0.31 & 0.22 & 80 & 0.00 & 0.92 \\
\hline $1,2,3,7,8,9-\mathrm{HexaCDF}$ & 0.00 & 0.00 & 0.00 & 0.13 & 0 & 0.00 & 0.00 \\
\hline $2,3,4,6,7,8-\mathrm{HexaCDF}$ & 0.26 & 0.18 & 0.25 & 0.13 & 87 & 0.00 & 0.65 \\
\hline $1,2,3,4,6,7,8$-HeptaCDF & 0.00 & 0.00 & 0.00 & 2.75 & 0 & 0.00 & 0.00 \\
\hline $1,2,3,4,7,8,9$-HeptaCDF & 0.00 & 0.00 & 0.00 & 0.13 & 0 & 0.00 & 0.00 \\
\hline OctaCDF (OCDF) & 0.00 & 0.00 & 0.00 & 2.00 & 13 & 0.00 & 0.00 \\
\hline Sum PCDD/Fs & 1.98 & 0.67 & 1.58 & - & - & 0.12 & 5.00 \\
\hline \multicolumn{8}{|l|}{$D L-P C B S$} \\
\hline РCB 77 (non-ortho) & 0.00 & 0.00 & 0.00 & 160.14 & 0 & 0.00 & 0.00 \\
\hline PCB 81 (non-ortho) & 0.00 & 0.00 & 0.00 & 15.95 & 0 & 0.00 & 0.00 \\
\hline РСВ 126 (non-ortho) & 17.46 & 12.59 & 11.60 & 3.96 & 100 & 5.73 & 45.54 \\
\hline PCB 169 (non-ortho) & 1.07 & 0.62 & 0.81 & 0.26 & 100 & 0.40 & 2.30 \\
\hline PCB 105 (ortho) & 508.86 & 305.62 & 449.02 & 161.11 & 100 & 174.60 & 1229.15 \\
\hline РСB 114 (ortho) & 40.97 & 20.47 & 39.89 & 14.26 & 100 & 15.56 & 76.59 \\
\hline РСВ 118 (ortho) & 974.06 & 674.84 & 825.27 & 473.91 & 87 & 0.00 & 2448.32 \\
\hline РCB 123 (ortho) & 13.83 & 10.23 & 11.78 & 6.84 & 87 & 0.00 & 36.80 \\
\hline РСВ 156 (ortho) & 88.70 & 59.15 & 65.68 & 19.88 & 100 & 25.03 & 201.19 \\
\hline РСВ 157 (ortho) & 21.94 & 15.33 & 15.60 & 2.37 & 100 & 5.67 & 52.30 \\
\hline РСB 167 (ortho) & 37.74 & 26.52 & 29.59 & 9.55 & 93 & 0.00 & 91.60 \\
\hline РСB 189 (ortho) & 6.28 & 3.73 & 5.13 & 1.35 & 100 & 1.38 & 14.29 \\
\hline Sum DL-PCBs & 1710.91 & 744.27 & 1454.38 & - & - & 264.85 & 4187.81 \\
\hline \multicolumn{8}{|l|}{ Indicator NDL-PCBS } \\
\hline PCB 28 & 802.62 & 703.43 & 618.67 & 150.00 & 87 & 0.00 & 2563.57 \\
\hline РCB 52 & 2608.66 & 2309.69 & 2136.58 & 150.00 & 87 & 0.00 & 8812.23 \\
\hline РCB 101 & 1315.04 & 1191.51 & 1130.27 & 150.00 & 93 & 0.00 & 4040.80 \\
\hline PCB 138 & 518.83 & 286.51 & 428.56 & 40.00 & 100 & 177.19 & 1201.65 \\
\hline PCB 153 & 796.40 & 423.15 & 670.05 & 40.00 & 100 & 313.58 & 1785.22 \\
\hline РСВ 180 & 213.45 & 126.77 & 177.47 & 40.00 & 100 & 56.01 & 454.93 \\
\hline Sum indicator NDL-PCBs & 6255.01 & 2743.43 & 5161.61 & - & - & 601.32 & 17441.80 \\
\hline
\end{tabular}

a Non-detected and $<$ LOQ reported as zero. 
$40 \mathrm{ng} \mathrm{g}^{-1}$ fat reported in the recent European Commission document (SANCO/13331, 2010) for the sum of the 6 indicator NDL-PCBs in raw milk. Bactrian NDL-PCB concentrations (mean $7.2 \pm$ $3.2 \mathrm{ng} \mathrm{g}^{-1}$ fat, median $6.6 \mathrm{ng} \mathrm{g}^{-1}$ fat, range $0.6-17.4 \mathrm{ng} \mathrm{g}^{-1}$ fat), were higher than dromedary concentrations (mean $5.1 \pm 2.0 \mathrm{ng} \mathrm{g}^{-1}$ fat, median $6.4 \mathrm{ng} \mathrm{g}^{-1}$ fat, range $1.3-8.3 \mathrm{ng} \mathrm{g}^{-1} \mathrm{fat}$ ), essentially because of the higher concentrations for PCB 52 and PCB 101 (Fig. 2a), which surprisingly appeared to contribute more than $60 \%$ to the sum of NDL-PCB concentration although limited to less than $10 \%$ for European dairies where this is the sum of PCB 138 and PCB 153 that typically account for more than $60 \%$ to the sum of NDL-PCB concentration (Fig. 2b). The reported high concentrations for PCB 52 and PCB 101 are not to be related to quantification or blank issues since respectively only $13 \%$ and $7 \%$ of the recorded data were below LOQs (Table 1). PCB 138 and PCB 153 concentrations were always above LOQs. Although it is known that some species differences can exist in the metabolism of dioxins (Olson, 1983), such an important difference in congener specific bio-accumulation or metabolization is unlikely to exist between camels and cows, such a difference in NDL-PCB profiles tends to indicate a possible difference in the route of exposure, such as ambient air and soil, in Kazakhstan, compared to European countries. One cannot exclude the possibility that the extensive use of trichlorobiphenyl mixtures by large capacitor plants until the beginning of the 1990s could somehow be related to this uncommon pattern. Recent reports (International POPs Elimination Project, 2006; Ishankulov, 2008) highlighted the lack of available information concerning disposal of PCB-containing waste from old capacitor plants or electric substations, as well as the need for a comprehensive inventory of PCBs reservoirs in Kazakhstan.

To the best of our knowledge, no other data have been reported for NDL-PCBs in Kazakh camel milk and thus make any national comparison impossible. Based on the present set of data, no significant differences were observed in terms of seasonal variation for NDL-PCB concentrations. Furthermore, it was not possible to unequivocally identify a particular geographical region which could be responsible for this specific trend. Data from the Aralsk region were nevertheless located in the upper part of the range, especially for PCB 52 and PCB 101 (Fig. 2c). Further measurement campaigns are needed to confirm those observations. Such campaigns should at least include the measurement of the classical 6 indicator NDL-PCBs, but could also be extended to a larger list of congeners to improve chances of source tracking by creating more detailed congener patterns that could be used in environmental forensic investigations. If those patterns then appear to be significantly different from classical ones, one might have to reconsider measuring only those 6 indicator NDL-PCBs to assess the total a

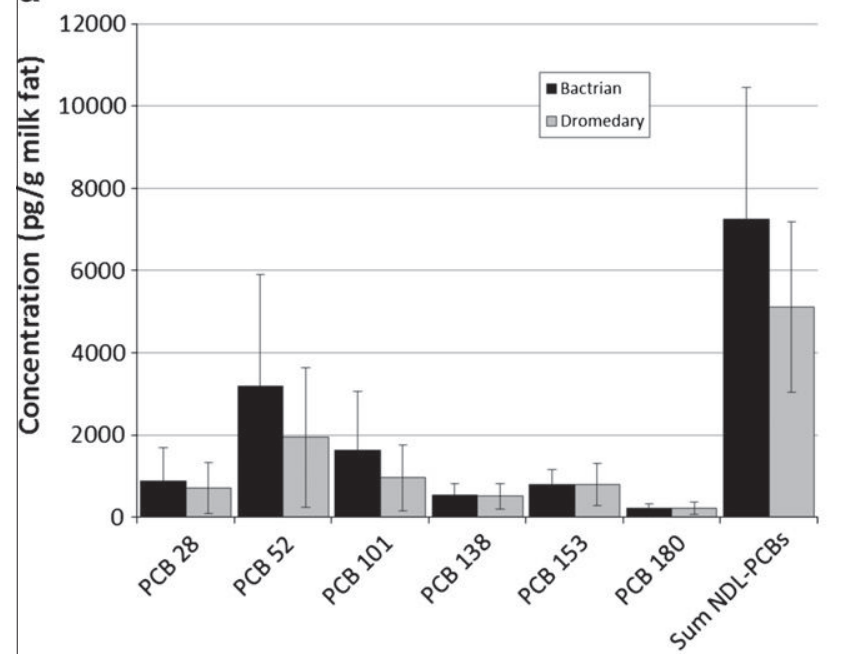

b

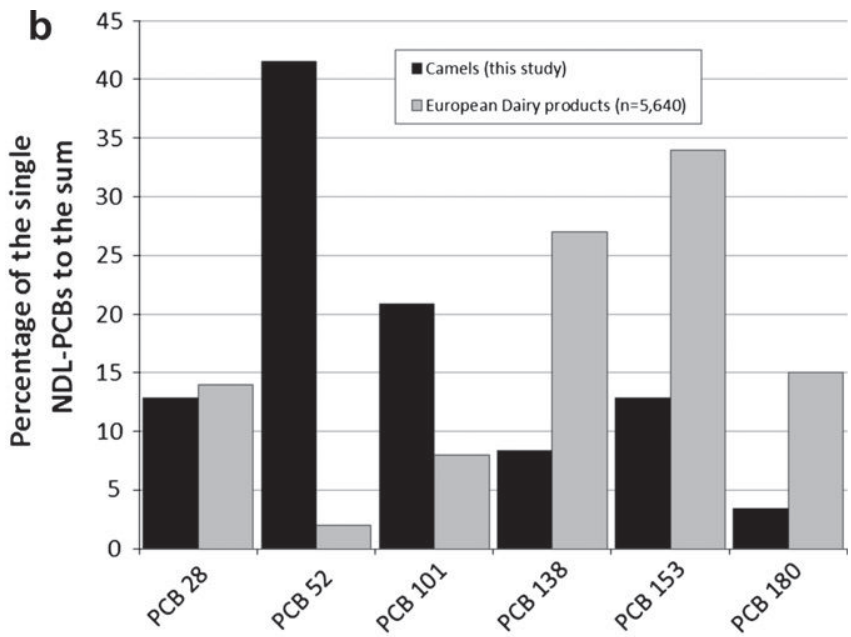

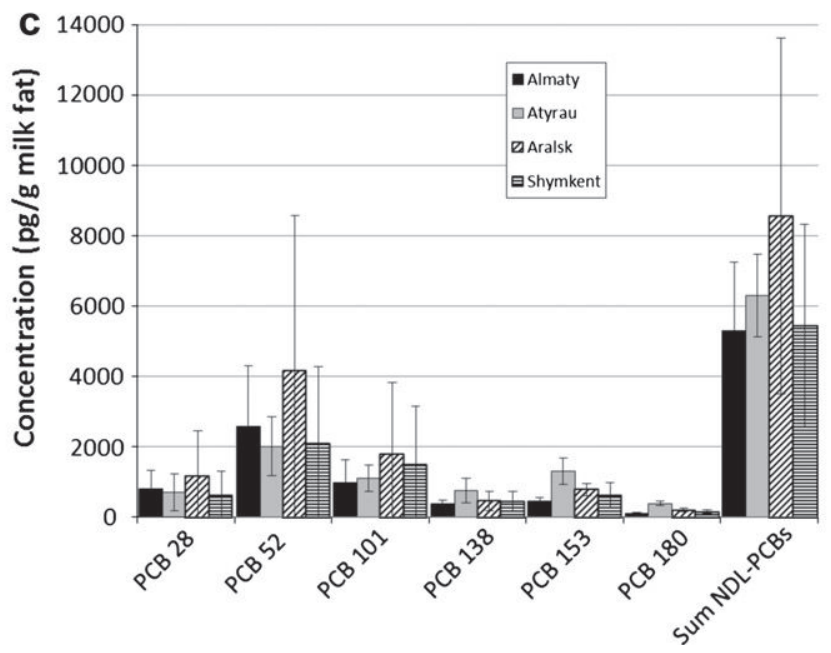

Fig. 2. Concentration levels of 6 NDL-PCBs of the camel milk samples by race (a), in contribution (\%) to the sum of the six with comparison with European dairy product levels (b), and by geographical localization (c). 


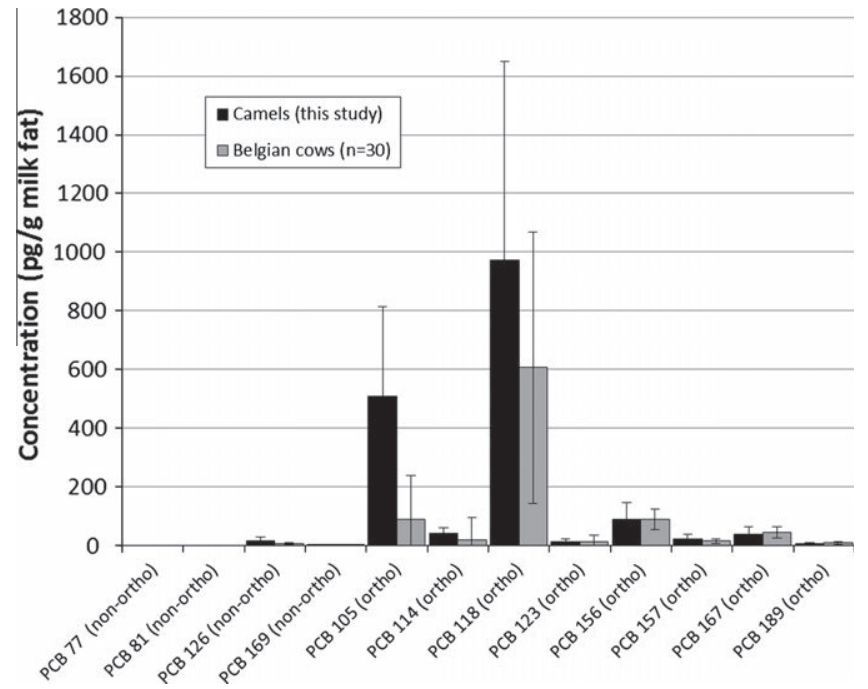

Fig. 3. Concentration levels of the 12 DL-PCBs of the camel milk samples with comparison with Belgian cow milk levels.

NDL-PCB content, as the accepted idea that they contribute to about $50 \%$ of the total NDL-PCB content (EFSA, 2005) was not upheld in this particular case. Additionally, because camel milk could be used as a human milk substitute and because intakes during the nursing period are known to be a couple of orders of magnitude higher than for adults, the unusual PCB 52 and PCB 101 pattern should be elucidated, as the lower chlorinated congeners are known to cause DNA damages (Schilderman et al., 2000).

\subsection{NO-PCB and MO-PCB concentrations}

The mean NO-PCB and MO-PCB level, based on the sum of PCB 77, PCB 81, PCB 126, PCB 169, РCB 105, РCB 114, РCB 118, PCB 123, PCB 156, PCB 157, PCB 167, and PCB 189 for all samples was $1.7 \pm 0.7 \mathrm{ng} \mathrm{g}^{-1}$ fat (median $1.5 \mathrm{ng} \mathrm{g}^{-1}$ fat, range $0.3-4.2 \mathrm{ng} \mathrm{g}^{-1}$ fat) (Table 1). Signals below LOQs we treated as equal to zero for calculations of concentrations. Based on median values, ratio analysis showed that the sum of the 6 indicator NDL-PCBs was 3.4 times higher than the sum of the 12 DL-PCBs, which is similar to what is reported in EU for dairy products (EFSA, 2010a). In terms of profiles, the DL-PCB congener distribution for camel milk looks similar to the one of Belgian cows, except for PCB 105 and PCB118 that are present at significantly higher mean concentrations for camel milk samples (Fig. 3). РСB 105, РСВ 118, and РСВ 156 are the major congeners for DL-PCBs, accounting for $92 \%$ of the sum of concentrations of DL-PCBs ( $88 \%$ for Belgian cows).

In terms of DL-PCB (sum of 4 NO-PCBs and 12 MO-PCBs) TEQ concentrations, the mean values for all camel milk samples were $2.01 \pm 1.26$ pg TEQ ${ }_{\text {WHO9s }} \mathrm{g}^{-1}$ fat (median $1.52 \mathrm{pg}^{\mathrm{T}} \mathrm{TEQ}{ }_{\text {WHO98 }} \mathrm{g}^{-1}$

Table 2

Average TEQ (TEQWHO98 and TEQWHO05) concentrations of selected PCDDs, PCDFs, and DL-PCBs measured in camel milk (Bactrian and dromedary, $n=15$ pooled samples) collected in various region of Kazakhstan.

\begin{tabular}{|c|c|c|c|c|c|c|c|c|c|c|c|c|}
\hline & \multicolumn{5}{|c|}{ Conc. pgTEQWHO98 $\mathrm{g}^{-1}$ milk fat $^{\mathrm{a}}$} & \multirow[t]{3}{*}{$\% \mathrm{TEQ}^{\mathrm{b}}$} & \multicolumn{5}{|c|}{ Conc. pgTEQWHO05 $\mathrm{g}^{-1}$ milk fat $^{\mathrm{a}}$} & \multirow[t]{3}{*}{$\% \mathrm{TEQ}$} \\
\hline & \multirow[t]{2}{*}{ Mean } & \multirow[t]{2}{*}{ SD } & \multirow[t]{2}{*}{ Median } & \multicolumn{2}{|c|}{ Range } & & \multirow[t]{2}{*}{ Mean } & \multirow[t]{2}{*}{ SD } & \multirow[t]{2}{*}{ Median } & \multicolumn{2}{|c|}{ Range } & \\
\hline & & & & Min & Max & & & & & Min & Max & \\
\hline \multicolumn{13}{|l|}{ Dioxins } \\
\hline 2,3,7,8-TetraCDD & 0.10 & 0.04 & 0.08 & 0.07 & 0.18 & 3.5 & 0.10 & 0.04 & 0.08 & 0.07 & 0.18 & 3.4 \\
\hline $1,2,3,7,8$-PentaCDD & 0.21 & 0.09 & 0.18 & 0.10 & 0.40 & 7.0 & 0.21 & 0.09 & 0.18 & 0.10 & 0.40 & 6.9 \\
\hline $1,2,3,4,7,8-H e x a C D D$ & 0.01 & 0.00 & 0.01 & 0.01 & 0.02 & 0.4 & 0.01 & 0.00 & 0.01 & 0.01 & 0.02 & 0.4 \\
\hline 1,2,3,6,7,8-HexaCDD & 0.02 & 0.01 & 0.01 & 0.01 & 0.03 & 0.5 & 0.02 & 0.01 & 0.01 & 0.01 & 0.03 & 0.5 \\
\hline $1,2,3,7,8,9-\mathrm{HexaCDD}$ & 0.01 & 0.00 & 0.01 & 0.01 & 0.01 & 0.4 & 0.01 & 0.00 & 0.01 & 0.01 & 0.01 & 0.4 \\
\hline $1,2,3,4,6,7,8$-HeptaCDD & 0.03 & 0.00 & 0.03 & 0.03 & 0.03 & 0.9 & 0.03 & 0.00 & 0.03 & 0.03 & 0.03 & 0.8 \\
\hline Octa CDD (OCDD) & 0.00 & 0.00 & 0.00 & 0.00 & 0.00 & 0.0 & 0.00 & 0.00 & 0.00 & 0.00 & 0.00 & 0.1 \\
\hline \multicolumn{13}{|l|}{ Furans } \\
\hline 2,3,7,8-TetraCDF & 0.06 & 0.00 & 0.06 & 0.06 & 0.06 & 2.0 & 0.06 & 0.00 & 0.06 & 0.06 & 0.06 & 2.0 \\
\hline $1,2,3,7,8$-PentaCDF & 0.00 & 0.00 & 0.00 & 0.00 & 0.00 & 0.1 & 0.00 & 0.00 & 0.00 & 0.00 & 0.00 & 0.1 \\
\hline 2,3,4,7,8-PentaCDF & 0.36 & 0.20 & 0.31 & 0.18 & 0.50 & 12.0 & 0.21 & 0.12 & 0.19 & 0.11 & 0.50 & 7.2 \\
\hline $1,2,3,4,7,8$-HexaCDF & 0.04 & 0.02 & 0.03 & 0.03 & 0.08 & 1.3 & 0.04 & 0.02 & 0.03 & 0.03 & 0.08 & 1.3 \\
\hline $1,2,3,6,7,8-\mathrm{HexaCDF}$ & 0.04 & 0.02 & 0.03 & 0.02 & 0.09 & 1.4 & 0.04 & 0.02 & 0.03 & 0.02 & 0.09 & 1.3 \\
\hline $1,2,3,7,8,9-\mathrm{HexaCDF}$ & 0.01 & 0.00 & 0.01 & 0.01 & 0.01 & 0.4 & 0.01 & 0.00 & 0.01 & 0.01 & 0.01 & 0.4 \\
\hline $2,3,4,6,7,8-\mathrm{HexaCDF}$ & 0.03 & 0.02 & 0.02 & 0.01 & 0.06 & 0.9 & 0.03 & 0.02 & 0.02 & 0.01 & 0.06 & 0.9 \\
\hline $1,2,3,4,6,7,8$-HeptaCDF & 0.03 & 0.00 & 0.03 & 0.03 & 0.03 & 0.9 & 0.03 & 0.00 & 0.03 & 0.03 & 0.03 & 0.9 \\
\hline $1,2,3,4,7,8,9$-HeptaCDF & 0.00 & 0.00 & 0.00 & 0.00 & 0.00 & 0.0 & 0.00 & 0.00 & 0.00 & 0.00 & 0.00 & 0.0 \\
\hline OctaCDF (OCDF) & 0.00 & 0.00 & 0.00 & 0.00 & 0.00 & 0.0 & 0.00 & 0.00 & 0.00 & 0.00 & 0.00 & 0.0 \\
\hline Sum PCDD/Fs & 0.94 & 0.22 & 0.84 & 0.59 & 1.49 & 31.9 & 0.80 & 0.15 & 0.73 & 0.53 & 1.49 & 26.8 \\
\hline \multicolumn{13}{|l|}{$D L-P C B S$} \\
\hline PCB 77 (non-ortho) & 0.02 & 0.00 & 0.02 & 0.02 & 0.02 & 0.5 & 0.02 & 0.00 & 0.02 & 0.02 & 0.02 & 0.5 \\
\hline PCB 81 (non-ortho) & 0.00 & 0.00 & 0.00 & 0.00 & 0.00 & 0.1 & 0.00 & 0.00 & 0.00 & 0.00 & 0.00 & 0.2 \\
\hline РCB 126 (non-ortho) & 1.75 & 1.26 & 1.16 & 0.57 & 4.55 & 59.2 & 1.75 & 1.26 & 1.16 & 0.57 & 4.55 & 58.6 \\
\hline РСВ 169 (non-ortho) & 0.01 & 0.01 & 0.01 & 0.00 & 0.07 & 0.4 & 0.03 & 0.02 & 0.02 & 0.01 & 0.07 & 1.1 \\
\hline PCB 105 (ortho) & 0.05 & 0.03 & 0.04 & 0.02 & 0.04 & 1.7 & 0.02 & 0.01 & 0.01 & 0.01 & 0.04 & 0.5 \\
\hline РCB 114 (ortho) & 0.02 & 0.01 & 0.02 & 0.01 & 0.02 & 0.7 & 0.01 & 0.01 & 0.01 & 0.00 & 0.02 & 0.4 \\
\hline РСВ 118 (ortho) & 0.10 & 0.06 & 0.08 & 0.05 & 0.73 & 3.5 & 0.31 & 0.18 & 0.25 & 0.14 & 0.73 & 10.4 \\
\hline PCB 123 (ortho) & 0.00 & 0.00 & 0.00 & 0.00 & 0.01 & 0.1 & 0.00 & 0.00 & 0.00 & 0.00 & 0.01 & 0.1 \\
\hline РСВ 156 (ortho) & 0.04 & 0.03 & 0.03 & 0.01 & 0.06 & 1.5 & 0.03 & 0.02 & 0.02 & 0.01 & 0.06 & 0.9 \\
\hline РСВ 157 (ortho) & 0.01 & 0.01 & 0.01 & 0.00 & 0.02 & 0.4 & 0.01 & 0.00 & 0.00 & 0.00 & 0.02 & 0.2 \\
\hline РСВ 167 (ortho) & 0.00 & 0.00 & 0.00 & 0.00 & 0.00 & 0.0 & 0.00 & 0.00 & 0.00 & 0.00 & 0.00 & 0.0 \\
\hline РCB 189 (ortho) & 0.00 & 0.00 & 0.00 & 0.00 & 0.00 & 0.0 & 0.00 & 0.00 & 0.00 & 0.00 & 0.00 & 0.1 \\
\hline Sum DL-PCBs & 2.01 & 1.26 & 1.52 & 0.69 & 5.53 & 68.1 & 2.18 & 1.27 & 1.66 & 0.77 & 5.53 & 73.2 \\
\hline Sum PCDD/Fs and DL-PCBs & 2.95 & 1.28 & 2.34 & 1.30 & 6.88 & 100.0 & 2.98 & 1.28 & 2.48 & 1.31 & 6.88 & 100.0 \\
\hline
\end{tabular}

Non-detected and $<$ LOQ reported as zero.

b \%Total DL-PCB + PCDD/F TEQ based on mean values. 
fat, range $0.69-5.53$ pg TEQwHogs $\mathrm{g}^{-1}$ fat) and $2.18 \pm 1.27 \mathrm{pg}$ TEQWHO05 $\mathrm{g}^{-1}$ fat (median $1.66 \mathrm{pg} \mathrm{TEQ}_{\text {WHO05 }} \mathrm{g}^{-1}$ fat, range $0.77-$ $5.53 \mathrm{pg} \mathrm{TEQ}_{\text {Who05 }} \mathrm{g}^{-1}$ fat) (Table 2). From a recent EFSA report (EFSA, 2010b) based on data issued form $19 \mathrm{EU}$ member states, Iceland, and Norway $(n=931)$, the mean value for DL-PCB TEQ concentrations for cow milk were $1.0 \pm 1.04 \mathrm{pg} \mathrm{TEQ}_{\text {WHo9s }} \mathrm{g}^{-1}$ fat

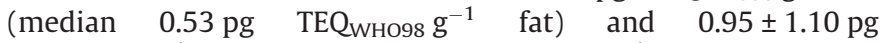
$\mathrm{TEQ}_{\text {who0 }} \mathrm{g}^{-1}$ fat (median $0.45 \mathrm{pg} \mathrm{TEQ}_{\text {who0 }} \mathrm{g}^{-1}$ fat) (Table 2). As for cow milk, PCB 126 and PCB 118 are the major contributors and represent, respectively, $87 \%$ and $5 \%$ of the DL-PCB TEQ ${ }_{W H O 98}$ concentrations and $80 \%$ and $14 \%$ of the DL-PCB TEQ ${ }_{W H O 05}$ concentrations, which correspond to the three-fold higher $\mathrm{TEF}_{\mathrm{WHO}}$ for PCB 118. The respective contributions of the NO-PCBs and MOPCBs to the DL-PCB TEQ concentrations are $88 \%$ and $12 \%$ of the DL-PCB TEQwHo9s concentrations and $83 \%$ and $17 \%$ of the DL-PCB $\mathrm{TEQ}_{\mathrm{WHO05}}$ concentrations. Although a decrease of $6 \%$ of the DLPCB TEQ value was reported for European cows when using TEFWHO05, an increase of $8 \%$ was observed for Kazakh camels. This increase is in opposition with the few trends available in the literature (Wittsiepe et al., 2007; Hong et al., 2009). The doubling of DL-PCB TEQ concentrations for Kazakh camels compared to European cows is due to the doubling of PCB 126 TEQ contribution and this congener TEF value has not been modified in the $\mathrm{TEF}_{\mathrm{WHO}}$ scale.
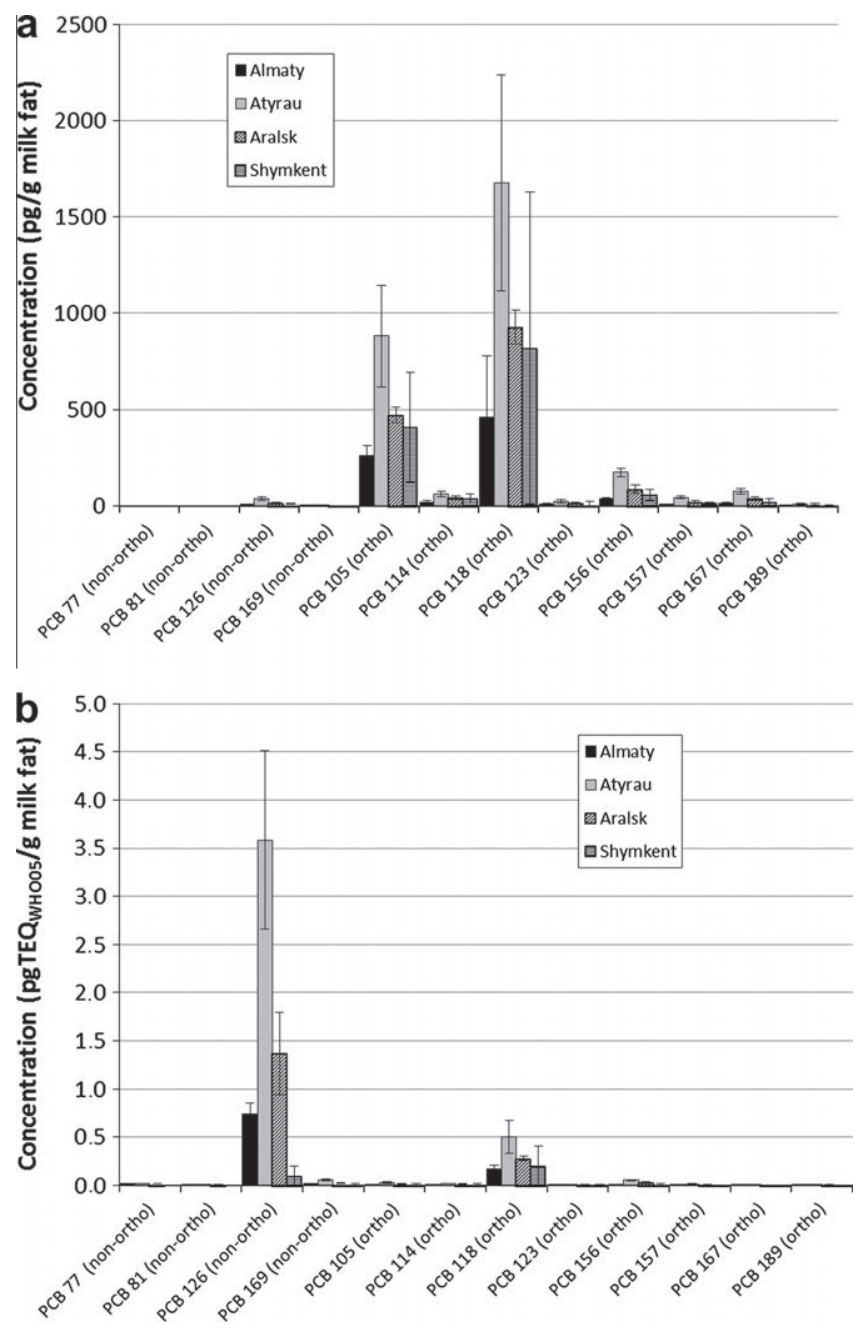

Fig. 4. Levels of 12 DL-PCBs of the camel milk samples by geographical region in concentration (a), and in $\mathrm{TEQ}_{\mathrm{WHO05}}$ (b).
No significant interracial or geographical trends were observed for DL-PCB profiles. However, concentrations of all DL-PCBs appeared to be significantly higher for samples collected in Atyrau region (Fig. 4a and b). For Almaty, Atyrau, Aralsk, and Shymkent, concentrations of the sum of TEQ ${ }_{\text {WHO05 }}$ DL-PCBs were, respectively, $0.90 \pm 0.12 \mathrm{pg} \mathrm{TEQ}_{W H O 05} \mathrm{~g}^{-1}$ fat, $4.29 \pm 0.94 \mathrm{pg} \mathrm{TEQ}_{W H O 05} \mathrm{~g}^{-1}$ fat,

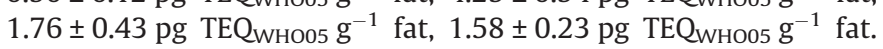
Those higher concentrations observed for Atyrau (Caspian Sea region) are partly responsible for the relatively elevated DL-PCB concentrations reported for camels. Because of the lack of laws and regulations on safe management of $\mathrm{PCB}$-containing equipment and materials in Kazakhstan, it is difficult to estimate if the use of capacitors and transformers by the power industry is significantly larger in that area. Additionally, one should also consider the fact that the Atyrau region hosts the field of Tengiz, the largest producing oil field of the country. Despite efforts to reduce the associated natural gas flaring, Kazakhstan is still in the top five of global gas flaring countries worldwide with more than five billions of cubic meters flared in 2008 (Kazakh law on petroleum, 1995; Rahimbergenov, 2008; National geophysical data center, 2010). The potential link between production of dioxin-like compounds during gas flaring and relatively elevated DL-PCB concentrations reported for camels in the region of Atyrau cannot be established so far, but the present data should motive additional investiga-
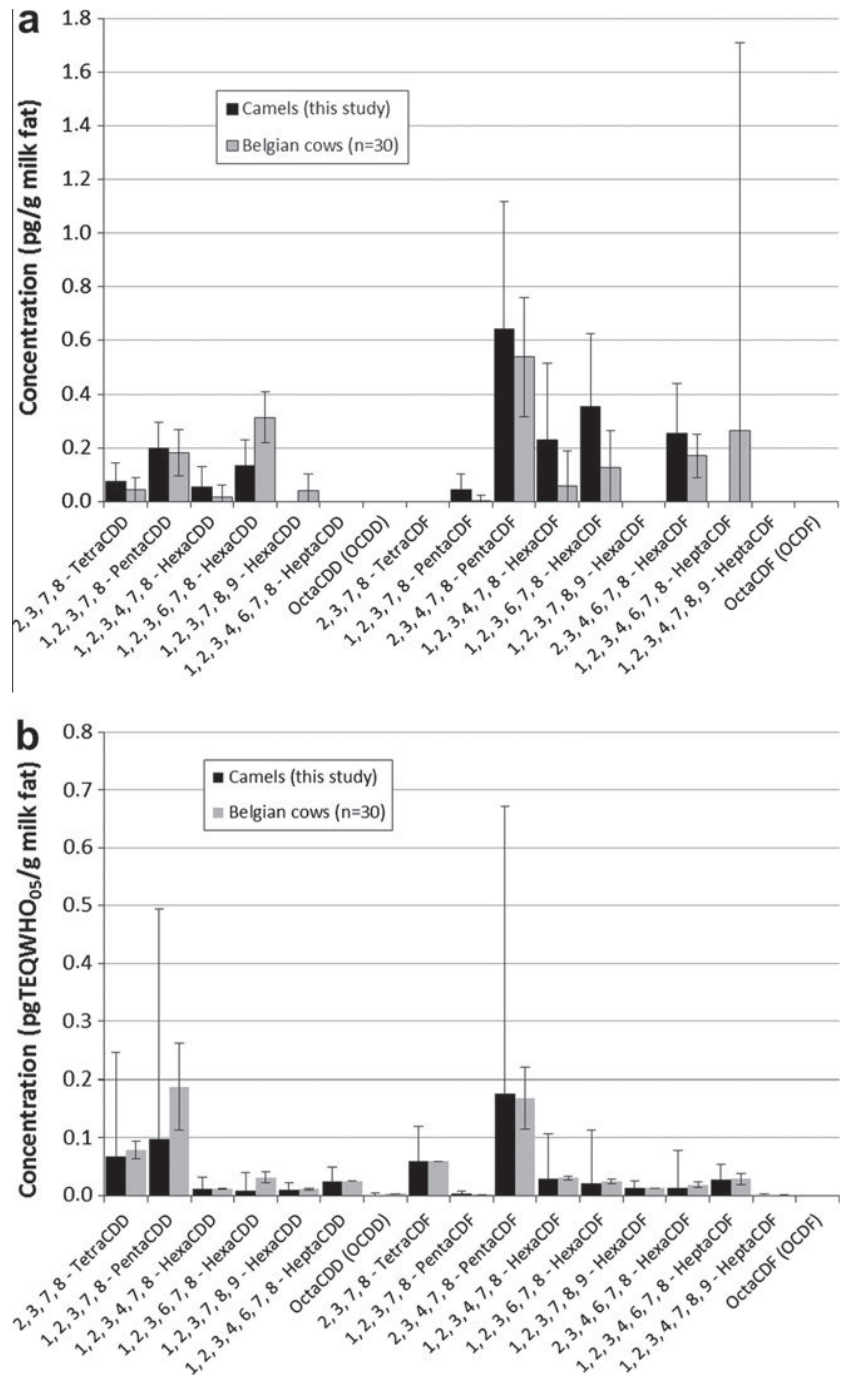

Fig. 5. Levels of the $17 \mathrm{PCDD} / \mathrm{Fs}$ of the camel milk samples with comparison with Belgian cow milk levels in concentration (a), and in TEQ ${ }_{\text {WHO05 }}(\mathrm{b})$. 
tions. Nevertheless, in their study of Kazakhstan human milk, Hooper et al. (1998) also reported higher DL-PCB levels for the region of Atyrau. Although not observed for NDL-PCBs, seasonal differences were observed for DL-PCB levels. The congener patterns were the same, but the concentrations were higher for spring samples with a mean DL-PCB value of $2.1 \pm 0.8 \mathrm{ng} \mathrm{g}^{-1}$ fat $\left(2.51 \pm 1.50\right.$ pg TEQ ${ }_{\text {WHO05 }} \mathrm{g}^{-1}$ fat $)$, compared to fall samples with a mean DL-PCB value of $1.3 \pm 0.6 \mathrm{ng} \mathrm{g}^{-1}$ fat $(1.80 \pm 0.97 \mathrm{pg}$ $\mathrm{TEQ}_{w \text { HO0 }} \mathrm{g}^{-1}$ fat). The feeding of camels in all the sampled farms was limited to the natural pastures. The seasonal changes in feeding were limited to the change in grass quality. At spring, the growth of the grasses was high and the environmental conditions were favorable for a higher absorption of pollutants than in autumn where the growth of the plants was highly reduced. The potential influence of the breeding season was not taken into account because of lack of data. For camels, the calving season is linked to the rutting season, which is limited in the year. All births occur between February and April. Few physiological effects were observed in our samples.

\section{4. $P C D D$ and $P C D F$ concentrations}

The abundance of PCDD/F congeners for all samples, based on the sum of 7 PCDDs and 10 PCDFs, is reported in Table 1 and compared to Belgian cow milk in Fig. 5a and b. Except for 1,2,3,6,7,8-hexaCDD, all PCDD/F congeners were present at higher concentrations in camel samples, although the same pattern is observed. A limited comparison can be done between 2,3,7,8-TCDD concentrations reported in the present study (mean $0.08 \pm 0$. $07 \mathrm{pg} \mathrm{g}^{-1}$ fat, median $0.08 \mathrm{pg} \mathrm{g}^{-1}$ fat, range $0.00-0.18 \mathrm{pg} \mathrm{g}^{-1}$ fat, $60 \%>$ LOQs) and concentrations of a previous study were one sample from state farm and one sample from a rural area were reported to be $0.89 \mathrm{pg} \mathrm{g}^{-1}$ fat and $<0.1 \mathrm{pg} \mathrm{g}^{-1}$ fat, respectively (Hooper et al., 1999). In terms of PCDD/F TEQ concentrations, the mean values for all camel milk samples were $0.94 \pm 0.22 \mathrm{pg}$ $\mathrm{TEQ}_{\text {WHO98 }} \mathrm{g}^{-1}$ fat (median $0.84 \mathrm{pg} \mathrm{TEQ}_{\text {WHO98 }} \mathrm{g}^{-1}$ fat, range 0.59$1.49 \mathrm{pg} \mathrm{TEQ}_{\text {wно9 }} \mathrm{g}^{-1}$ fat) and $0.80 \pm 0.15 \mathrm{pg}^{\mathrm{TEQ}} \mathrm{WHO05} \mathrm{g}^{-1}$ fat

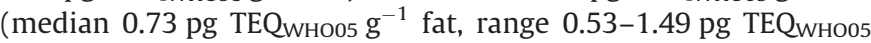
$\mathrm{g}^{-1}$ fat) (Table 2). Such a $15 \%$ decrease is what is also reported

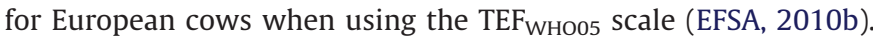
Those camel PCDD/F TEQ concentrations are slightly higher than the EU cow concentrations $\left(0.78 \pm 1.06 \mathrm{pg} \mathrm{TEQ}_{\mathrm{WHO} \text { \% }} \mathrm{g}^{-1}\right.$ fat, median 0.45 pg TEQ ${ }_{\text {WHO9s }} \mathrm{g}^{-1}$ fat, $0.67 \pm 0.86$ pg TEQ $_{\text {w }}$ o0 $\mathrm{g}^{-1}$ fat, median 0.39 pg TEQ ${ }_{W H O 05} \mathrm{~g}^{-1}$ fat), but well below the maximum level of 3.00 pg TEQwHogs $\mathrm{g}^{-1}$ fat set by EU Commission Regulation 2006/1881 (Commission Regulation 1881, 2006) for dairy products. The three congeners $2,3,7,8$-TCDD (11\% TEQ ${ }_{\text {WHO98 }}, 13 \%$ TEQ-

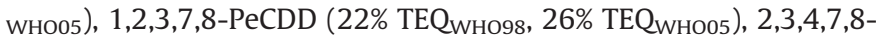
PeCDF (38\% $\mathrm{TEQ}_{\mathrm{WHO98}}, 27 \% \mathrm{TEQ}_{\mathrm{WHO05}}$ ) contributed to $71 \%$ of the

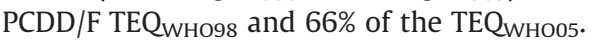

The sum of PCDD/F TEQ and DL-PCB TEQ for all camel milk samples was $2.95 \pm 1.28 \mathrm{pg} \mathrm{TEQ}_{\text {whogs }} \mathrm{g}^{-1}$ fat (median $2.34 \mathrm{pg}$ $\mathrm{TEQ}_{W \text { Hо98 }} \mathrm{g}^{-1}$ fat, range $1.30-6.88 \mathrm{pg} \mathrm{TEQ}_{\text {WHO98 }} \mathrm{g}^{-1}$ fat) and $2.98 \pm 1.28$ pg TEQ ${ }_{W H O 05} \mathrm{~g}^{-1}$ fat (median $2.48 \mathrm{pg} \mathrm{TEQ}_{\text {WHO05 }} \mathrm{g}^{-1}$ fat, range 1.31-6.88 pg TEQ ${ }_{\text {wно0 }} \mathrm{g}^{-1}$ fat) (Table 2). This represents $1 \%$ decrease when using the $\mathrm{TEF}_{\mathrm{WHO05}}$ scale. This is much less than the expected $10 \%$ decrease for dairy products (EFSA, 2010b) and this is due to the DL-PCB TEQ increase discussed earlier. The concentrations in camel's milk are slightly higher than the EU cow concentrations $\left(1.78 \pm 2.06 \mathrm{pg} \mathrm{TEQ}_{\text {WHO98 }} \mathrm{g}^{-1}\right.$ fat, median $1.04 \mathrm{pg}$ TEQ ${ }_{\text {WHO98 }} \mathrm{g}^{-1}$ fat, $1.61 \pm 1.94 \mathrm{pg}$ TEQ ${ }_{\text {Hнo5 }} \mathrm{g}^{-1}$ fat, median $0.90 \mathrm{pg}$ TEQwHO05 $\mathrm{g}^{-1}$ fat), but well below the maximum level of $6.00 \mathrm{pg}$ $\mathrm{TEQ}_{\text {whо98 }} \mathrm{g}^{-1}$ fat set by EU Commission Regulation 2006/1881 (Commission Regulation 1881, 2006) for dairy products.

Among camel samples, two pools exceeded the EU maximum level value of $6.00 \mathrm{pg} \mathrm{TEQ}_{\mathrm{WHO}} \mathrm{g}^{-1}$ fat for the sum of PCDD/Fs and DL-PCBs. Both samples, one from Bactrian (6.4 pg TEQwHо9s $\mathrm{g}^{-1}$ fat, with $1.8 \mathrm{pg} \mathrm{TEQ}_{\mathrm{WHO}} \mathrm{g}^{-1}$ fat for PCDD/Fs and $4.6 \mathrm{pg}$ $\mathrm{TEQ}_{W H O 98} \mathrm{~g}^{-1}$ fat for DL-PCBs) and one from dromedary $(6.7 \mathrm{pg}$ $\mathrm{TEQ}_{\text {WHO98 }} \mathrm{g}^{-1}$ fat, with $1.6 \mathrm{pg} \mathrm{TEQ}_{\text {wHO98 }} \mathrm{g}^{-1}$ fat for PCDD/Fs and $5.1 \mathrm{pg} \mathrm{TEQ}_{\text {wHogs }} \mathrm{g}^{-1}$ fat for DL-PCBs), were issued from Atyrau and were collected in spring. Fall samples from this area were also significantly higher than the mean values. Bactrian was $4.5 \mathrm{pg}$ $\mathrm{TEQ}_{\text {Whо98 }} \mathrm{g}^{-1}$ fat $\left(1.1 \mathrm{pg}\right.$ TEQ ${ }_{\text {who9s }} \mathrm{g}^{-1}$ fat for PCDD/Fs and $3.4 \mathrm{pg}$ TEQ ${ }_{W H O 98} \mathrm{~g}^{-1}$ fat for DL-PCBs) and dromedary was $4.0 \mathrm{pg}$ $\mathrm{TEQ}_{\text {Wно9 }} \mathrm{g}^{-1}$ fat $\left(1.1 \mathrm{pg} \mathrm{TEQ}_{\text {Wно9 }} \mathrm{g}^{-1}\right.$ fat for PCDD/Fs and $2.9 \mathrm{pg}$ TEQ ${ }_{\text {whо98 }} \mathrm{g}^{-1}$ fat for DL-PCBs) (Fig. 6). These data clearly indicate that the geographical localization of Atyrau is more impregnated by PCDD/Fs and DL-PCBs than the other regions included in this study. Both PCDD/F and DL-PCB concentrations were higher than for all other samples. Based on the EU Commission Regulation 2006/1881 (Commission Regulation 1881, 2006), products collected in Atyrau in spring should not be consumed to ensure efficient protection of public health. As it is the case for Baltic region fish species, one could argue that a special derogation could be granted for local consumption as camel milk product consumption

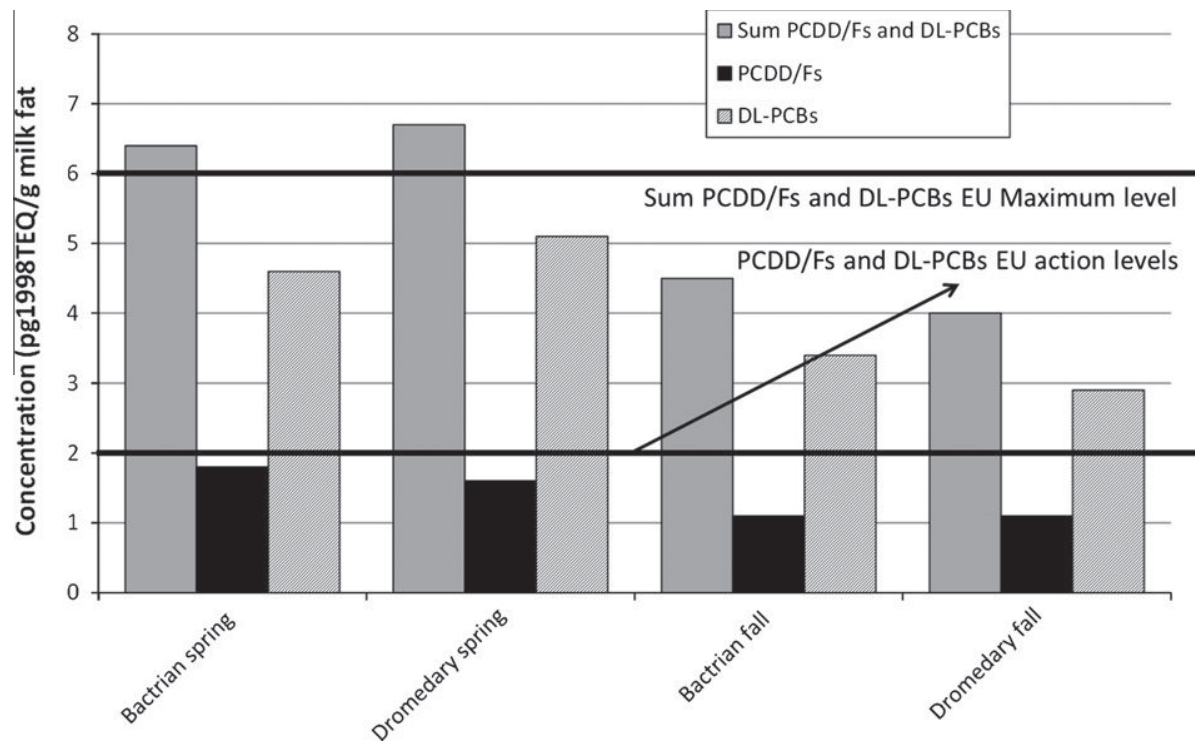

Fig. 6. Levels of PCDD/Fs and DL-PCBs (TEQ $\left.{ }_{W H O 98}\right)$ for samples collected in the region of Atyrau. 


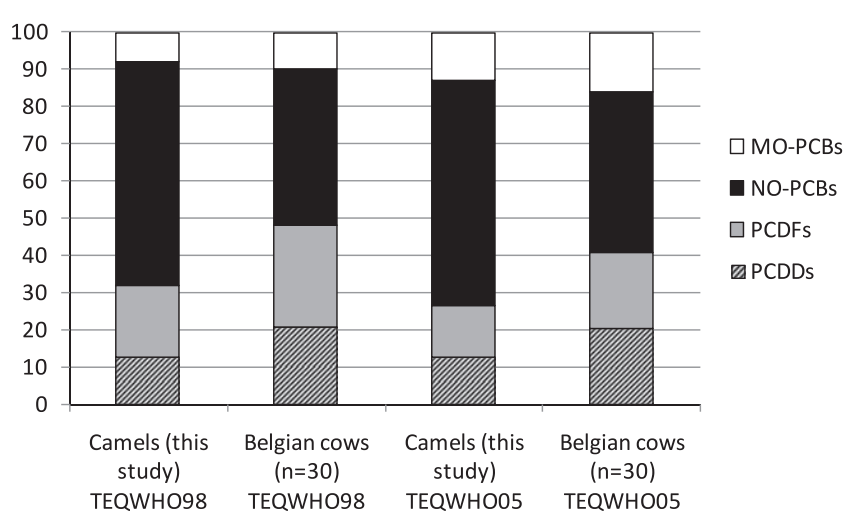

Fig. 7. Relative contributions (\%) of NO-PCBs, MO-PCBs, PCDDs, and PCDFs to the total $\mathrm{TEQ}_{\mathrm{WHO} \text { (s) }}$ and $\mathrm{TEQ}_{\mathrm{WHO0}}$ level for the camel milk samples with comparison with Belgian cow milk levels.

is supposed to have a positive health impact (see introduction part). However, because each of these Atyrau four sample pools exhibited DL-PCB concentrations higher than the DL-PCB EU action level (2 pg TEQ ${ }_{\text {whoss }} \mathrm{g}^{-1}$ fat) (Fig. 6), it is recommended to initiate investigations to identify the source of contamination, take measures to reduce or eliminate the source of contamination, and check for the presence of NDL-PCBs (Commission Recommendation 2006/88/EC, 2006).

For both DL-PCB and PCDD/F data, all the detected (1,2,3,7,8,9hexaCDD, 1,2,3,4,6,7,8-heptaCDD, OCDD, 2,3,7,8-TCDF, 1,2,3,7,8,9hexaCDF, 1,2,3,4,6,7,8-heptaCDF, 1,2,3,4,7,8,9-heptaCDF, OCDF, PCB 77, and PCB 81 were below LOQs) of the 29 congeners expressed higher concentration concentrations, although NDL-PCB concentrations were similar to the other localizations. The information collected at the time of sampling did not allow an explanation of those elevated concentrations. Further dedicated specific sampling should be carried out to further investigate the situation and demonstrate the recurrence or not of such non-compliant samples, especially in the proximity of the field of Tengiz. In terms of seasonal trend, it appeared that the mean of the sum of PCDD/F and DL-PCB TEQ concentrations tend to be higher in spring than in fall $(3.38 \pm$ $1.51 \mathrm{pg} \mathrm{TEQ}_{\text {wно05 }} \mathrm{g}^{-1}$ fat in spring, $2.51 \pm 0.98 \mathrm{pg} \mathrm{TEQ}_{\text {whо0 }} \mathrm{g}^{-1}$ fat in fall). No species differences were recorded.

Fig. 7 shows the relative contributions of PCDFs, PCDDs, and DL-PCBs (NO-PCBs and MO-PCBs) to the total TEQ value for Kazakh camels and compare them to Belgian cows. The larger contribution of NO-PCBs for camels is due to PCB 126. The use of TEF WHO05 $_{\text {scale }}$ tends to reduce the \% contribution of PCDFs (through the reduction of the 2,3,4,7,8-PeCDF TEF) and increase the \% contribution of MOPCBs.

\section{Summary and conclusions}

Despite the concern for the potential presence of POPs in camel products, this is the first report on the concentrations of selected NDL-PCBs, DL-PCBs, and PCDD/Fs in camel milk collected in the Republic of Kazakhstan. Although the number of samples was relatively limited, this study is representative of general Kazakhstan concentrations because of the fact that those samples were issued from pooling of a large number of specimen collected in different regions, during different seasons, and for two different camel species.

NDL-PCB concentrations measured in camel milk $(6.3 \pm 2$. $7 \mathrm{ng} \mathrm{g}^{-1}$ fat) were lower than average EU cow milk concentrations $\left(9.2 \pm 3.4 \mathrm{ng} \mathrm{g}^{-1}\right.$ fat $)$ and far below the maximum value of $40 \mathrm{ng} \mathrm{g}^{-1}$ fat proposed by the EU. The high contribution of PCB 52 and PCB 101 $(>60 \%)$ to the sum of the 6 indicator NDL-PCBs however indicates possible differences in the route of exposure to PCBs in Kazakhstan.
For MO-PCBs, PCB 105 and PCB 118 also appeared to be present at higher concentration concentrations in camel milk, relative to EU cow milk. For all samples, 2,3,7,8-TCDD concentrations were very low $\left(0.08 \pm 0.07 \mathrm{pg} \mathrm{g}^{-1}\right.$ fat $)$ and 2,3,4,7,8-PeCDF was the major contributor $(27 \%)$ to the PCDD/F TEQwнo5. All samples were below the maximum level of 3.00 pg PCDD/F TEQ ${ }_{\text {WHogs }} \mathrm{g}^{-1}$ fat set by EU. PCB 126 was the major contributor $(80 \%)$ to the DL-PCB TEQ ${ }_{W H O 05}$. Con-

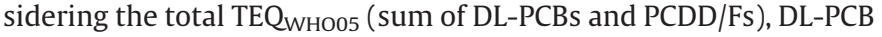
and PCDD/F contributions were in the ratio of $3-1$. A decrease of only $1 \%$ of the total TEQ was observed when using the $\mathrm{TEF}_{\mathrm{WHO05}}$ scale instead of the TEF

In general, the concentrations were higher in the region of Atyrau, independently of seasons or species, with two pools exceeding the maximum EU value of 6.00 pg TEQ $_{\text {WHO9s }} \mathrm{g}^{-1}$ fat. This suggests that the human exposure in the Caspian Sea region of Atyrau is expected to be higher than in the other regions studied here. This point could be linked to the importance of oil extraction in the area which is considered to be the most risk for air and soil pollution in steppe regions around (Ongarbayev and Mansurov, 2008). Further measurement campaigns are needed to confirm those observations and potentially locate specifically contaminated rural area that might have been hidden by the pooling procedure, especially in the Atyrau region. Because of the high consumption of camel milk based products, this is of prime interest to implement environmental quality control of dairy cattle to reduce risks of human exposure. This is especially true in the eventuality where camel milk would be promoted and used as a complement or a substitute to mother's milk for toddler feeding.

\section{Appendix A. Supplementary material}

Supplementary data associated with this article can be found, in the online version, at doi:10.1016/j.chemosphere.2011.06.097.

\section{References}

Agency of Statistic of the Republic of Kazakhstan, 2010. <http://www.stat.kz>. Agrawal, R.P., Swami, S.C., Beniwal, R., Kochar, D.K., Sahani, M.S., Tuteja, F.C., Ghouri, S.K., 2003. Effect of camel milk on glycemic control risk factors and diabetes quality of life in type-1 diabetes: a randomized prospective controlled study. J. Camel Res. Pract. 10, 45-50.

Baranik, V., Borysova, O., Stolberg, F., 2004. The Caspian Sea region: environmental change. Ambio 33, 45-51.

Commission Directive 2002/70/EC of 26 July, 2002. Establishing requirements for the determination of levels of dioxins and dioxin-like PCBs in feedingstuffs. Off. J. Eur. Commun. L209, 15-21.

Commission Recommendation 2006/88/EC of 6 February, 2006. On the reduction of the presence of dioxins, furans and PCBs in feedingstuffs and foodstuffs. Off. J. Eur. Commun. L42, 26-28.

Commission Regulation (EC) No 1881/2006 of 19 December, 2006. Setting maximum levels for certain contaminants in foodstuffs. Off. J. Eur. Commun. L364, 5-24.

Djangabilov, A.K., Bekishev, A.C., Mamirova, T.N., 2000. Medical properties of camel milk and shubat. In: Proceeding 2nd Int. Camelid Conf. "Agroeconomics of Camelid Farming", 8-12 September, Almaty, Kazakhstan, p. 100.

EFSA, 2005. Scientific report, opinion of the scientific panel on contaminants in the food chain on a request from the Commission related to the presence of nondioxin-like polychlorinated biphenyls (PCB) in feed and food. EFSA J. 284, 1137.

EFSA, 2010a. Scientific report, results of the monitoring of non dioxin-like PCBs in food and feed. EFSA J. 8, 1701-1736.

EFSA, 2010b. Scientific report, results of the monitoring of dioxin levels in food and feed. EFSA J. 8, 1385-1421.

El Agamy, E.I., 2000. Effect of heat treatment on camel milk proteins with respect to antimicrobial factor: a comparison with cow's and buffalo milk proteins. Food Chem. 68, 227-232.

El-Hatmi, H., Khorchani, T., Attia, H., 2006. Characterization and composition of camel's (Camelus dromedarius) colostrum and milk. Microbiol. Hyg. Alim. 18, 13-17.

Erdinger, L., Eckl, P., Ingel, F., Khussainova, S., Utegenova, E., Mann, V., Gabrio, T., 2004. The Aral sea disaster - human biomonitoring of Hg, As, HCB, DDE, and PCBs in children living in Aralsk and Akchi, Kazakhstan. Int. J. Hyg. Environ. Health 207, 541-547. 
Faye, B., Konuspayeva, G., Messad, S., Loiseau, G., 2008. Discriminant milk components of Bactrian camel (Camelus bactrianus), dromedary (Camelus dromedarius) and hybrids. Dairy Sci. Technol. 88, 607-617.

Faye, B., Sinyavskiy, Y., 2008. Impact of Pollution on Animal Products. NATO Science for Peace and Security Series - C: Environmental Security. Springer, Dordrecht.

Focant, J.-F., Eppe, G., Massart, A.-C., Scholl, G., Pirard, C., De Pauw, E., 2006. Highthroughput biomonitoring of dioxins and polychlorinated biphenyls at the subpicogram level in human serum. J. Chromatogr. A 1130, 97-107.

Focant, J.-F., Eppe, G., Pirard, C., De Pauw, E., 2001. Fast clean-up for polychlorinated dibenzo-p-dioxins, dibenzofurans and coplanar polychlorinated biphenyls analysis of high-fat-content biological samples. J. Chromatogr. A 925, 207-221.

Focant, J.-F., Eppe, G., Pirard, C., Massart, A.-C., Andre, J.-E., De Pauw, E., 2002. Levels and congener distributions of PCDDs, PCDFs and non-ortho PCBs in Belgian foodstuffs - assessment of dietary intake. Chemosphere 48, 167-179.

Focant, J.-F., Pirard, C., De Pauw, E., 2004. Automated sample preparationfractionation for the measurement of dioxins and related compounds in biological matrices: a review. Talanta 63, 1101-1113.

Focant, J.-F., Pirard, C., Massart, A.-C., De Pauw, E., 2003. Survey of commercial pasteurised cows' milk in Wallonia (Belgium) for the occurrence of polychlorinated dibenzo-p-dioxins, dibenzofurans and coplanar polychlorinated biphenyls. Chemosphere 52, 725-733.

Food and Agriculture Organization of the United Nations, 2010. <http://faostat. fao.org>

Hong, B., Garabrant, D., Hedgeman, E., Demond, A., Gillespie, B., Chen, Q., Chang, C.W., Towey, T., Knutson, K., Franzblau, A., Lepkowski, J., Adriaens, P., 2009. Impact of WHO 2005 revised toxic equivalency factors for dioxins on the TEQs in serum, household dust, and soil. Chemosphere 76, 727-733.

Hooper, K., Chuvakova, T., Kazbekova, G., Hayward, D., Tulenova, A., Petreas, M.X. Wade, T.J., Benedict, K., Cheng, Y.-Y., Grassman, J., 1999. Analysis of breast milk to assess exposure to chlorinated contaminants in Kazakhstan: sources of 2,3,7,8-tetrachlorodibenzo-p-dioxin (TCDD) exposures in an agricultural region of Southern Kazakhstan. Environ. Health Perspect. 107, 447-457.

Hooper, K., Petreas, M.X., Chuvakova, T., Kazbekova, G., Druz, N., Seminova, G., Sharmanov, T., Hayward, D., She, J., Vista, P., Winkler, J., McKinney, M., Wade, T.J., Grassman, J., Stephens, R.D., 1998. Analysis of breast milk to assess exposure to chlorinated contaminants in Kazakhstan: high levels of 2,3,7,8 Tetrachlorodibenzo-p-dioxin (TCDD) in agricultural villages of Southern Kazakhstan. Environ. Health Perspect. 106, 797-806.

International POPs Elimination Project (IPEP). Astanina, L., 2006. PCB Contamination in East Kazakhstan Oblast and other Regions of the Republic of Kazakhstan: Territory Monitoring and Inventories of PCBs Sources as Options to Address the Problem. <http://www.ipen.org/ipepweb1/library/ ipep_pdf_reports/3kaz\%20pcb\%20contamination\%20in\%20east\%20kazakhstan. pdf>.

Ishankulov, M., 2008. PCB-Contaminated areas in Kazakhstan and analysis of PCB impact on human health experience. In: Mehmetli, E., Koumanova, B. (Eds.), The Fate of Persistent Organic Pollutants in the environment. Springer, Dordrecht pp. 387-403.

Jensen, S., Mazhitova, Z., Zetterström, R., 1997. Environmental pollution and child health in the Aral Sea region of Kazakhstan. Sci. Tot. Environ. 206, 187-193.

Kazakh Law on Petroleum, 1995. Kazakstan: 1995 Petroleum Law (Edict 2350 Dated 28 June 1995) with Amendments Effective 1 September 1999 Incorporated: Basic Oil Laws \& Contracts: Russia \& NIS: Supplement 46.
Konuspayeva, G., Faye, B., Loiseau, G., Levieux, D., 2006. Lactoferrin and Immunoglobin content in camel milk from Kazakhstan. J. Dairy Sci. 90, 38-46.

Konuspayeva, G., Faye, B., Loiseau, G., 2008. The composition of camel milk: a metaanalysis of the literature data. J. Food Compos. Anal. 22, 95-101.

Konuspayeva, G., Faye, B., Loiseau, G., Narmuratova, M., Ivashchenko, A. Meldebekova, A., Davletov, S., 2010. Physiological change in camel milk composition (Camelus dromedarius) 2: physico-chemical composition of colostrum. Trop. Anim. Health Prod. 42, 501-505.

Konuspayeva, G., Jurjanz, S., Loiseau, G., Barci, V., Akhmetsadykova, S., Meldebekova, A., Faye, B., 2011. Contamination of camel milk (heavy metals, organic pollutants and radionuclides) in Kazakhstan. J. Environ. Prot. 2, 90-96.

Lederman, S.A., 1996. Environmental contaminants in breast milk from the Central Asian Republics. Reprod. Toxicol. 10, 93-104.

Lutter, C., Iyengar, V., Barnes, R., Chuvakova, T., Kazbekova, G., Sharmanov, T., 1998. Breast milk contamination in Kazakhstan: implications for infant feeding. Chemosphere 37, 1761-1772.

National geophysical data center, 2010. Global gas flaring country data. <http:// www.ngdc.noaa.gov/dmsp/interest/gas_flares_countries2.php?c=Kazakhstan> and <http://www.esrl.noaa.gov/gmd/annualconference/pdfs/5-Elvidge.pdf>.

Olson, J.R., 1983. Metabolism and disposition of 2,3,7,8-tetrachlorodibenzo-pdioxin (TCDD) in guinea-pigs. Toxicol. Appl. Pharmacol. 85, 263-273.

Ongarbayev, Y., Mansurov, Z., 2008. Study of composition and properties of oil pollution. In: Faye, B., Sinyavskiy, Y. (Eds.), Proceedings of International Workshop, "Impact of pollution on animal products". Almaty (Kazakhstan), 27-30 September 2007, pp. 3-12.

Rahimbergenov, 2008. Regulating flaring and utilization of oil and gas: experience of Kazakhstan. In: Proceedings of "The Flairing and Venting Reduction and Natural Gas Utilization Forum", Amsterdam (The Netherlands), 3-5 December 2008.

Restani, P., Gaiaschi, A., Plebani, A., Beretta, B., Cavagni, G., Fiocchi, A., Poiesi, C. Velona, T., Ugazio, A.G., Galli, C.L., 1999. Cross-reactivity between milk proteins from different animal species. Clin. Exp. Allergy 29, 997-1004.

Rüegg, M.W., Farah, Z., 1991. Melting curves of camel milk fat. Milchwissenschaft 46 (6), 361-362.

SANCO/13331/2010, Draft document. <http://ec.europa.eu/dgs/health_consumer/ index_en.htm>.

Schilderman, P.A., Maas, L.M., Pachen, D.M., de Kok, T.M., Kleinjans, J.C., van Schooten, F.J., 2000. Induction of DNA adducts by several polychlorinated biphenyls. Environ. Mol. Mutagen. 36, 79-86.

Serikbaeva, A.D., Toktamysova, A.B., 2000. Proteines du lait de chamelle. Belki verblyujego moloka. In: Proceeding 2nd Int. Camelid Conf. 'Agroeconomics of camelid farming', 8-12 September, Almaty, Kazakhstan, p. 97.

She, J., Petras, M.X., Visita, P., McKinney, M., Sy, F.J., Winkler, J.J., Hooper, K., Stephens, R.D., 1998. Congener-specific analysis of PCBs in human milk from Kazakhstan. Chemosphere 37, 431-442.

Wittsiepe, J., Fürst, P., Wilhelm, M., 2007. The 2005 World Health Organization reevaluation of TEFs for dioxins and dioxin-like compounds - what are the consequences for German human background levels? Int. J. Hyg. Environ. Health 210, 335-339.

Yagil, R., Van Creveld, C., 2000. Medical use of camel milk - fact or fancy? In: Proceeding 2nd Int. Camelid Conf. "Agroeconomics of Camelid Farming", 8-12 September, Almaty, Kazakhstan, p. 30. 